J-DEPACE, Volume 2, Nomor 1, Juni 2019, Hal. 75 - 86

Tersedia online di:http://jurnal.lpmiunvic.ac.id/index.php/jpkm

\title{
PENERAPAN METODE SIMPLEKS UNTUK MENGHASILKAN \\ KEUNTUNGAN MAKSIMUM PADA PENJUAL BUAH PINANG
}

\author{
Matheus Supriyanto Rumetna, Tirsa Ninia Lina, Razni Paknawan, Filemon, \\ Bryan Siwalette, Andriano, Rezty Deviana \\ Program Studi Sistem Informasi, Universitas Victory Sorong \\ email: matheus.rumetna@gmail.com
}

\begin{abstract}
ABSTRAK
Banyak masyarakat Kota Sorong yang menjual buah pinang untuk memenuhi kebutuhan hidup, salah satunya yaitu Mama Desi. Permasalahan yang dihadapi oleh penjual pinang Mama Desi adalah bagaimana menentukan jumlah penjualan yang optimum, sehingga diperoleh keuntungan penjualan yang maksimum. Masalah ini dapat diselesaikan dengan menggunakan Metode Simpleks yang merupakan salah satu bagian dari Program Linier dengan tujuan membantu Mama Desi dalam pengambilan keputusan serta meningkatkan keuntungan penjualan buah pinang. Hasil perhitungan penjualan buah pinang ini, keuntungan maksimum yang dapat diperoleh adalah senilai Rp 1.500 .000 setiap bulan.
\end{abstract}

Kata kunci: Program Linier, Metode Simpleks, Maximum Profit

\section{ABSTRACT}

Many people in Sorong City sell Pinang fruit to fulfill their daily needs; one of them is Mama Desi. The problem faced by the seller of Pinang Mama Desi is how to determine the optimum number of sales so that the maximum sales profit obtained. This problem can solve by using the Simplex Method, which is one part of a linear program to help Mama Desi in making decisions and increasing profits from selling Pinang fruit. Results of calculating the sale of Pinang fruit, the maximum benefit that can obtain is IDR 1,500,000 every month.

Keyword: Linear Programming, Simplex Method, Maximum Profit

\section{PENDAHULUAN}

Pinang merupakan buah yang sangat digemari dalam kehidupan orang Papua. Buah dari pohon pinang yang tergolong "Rumpun Palma" ini pun menjadi salah satu bagian dari tradisi masyarakat Papua. Buah pinang sangat laris diperdagangkan seperti layaknya orang menjual rokok. Tak hanya itu, jual beli buah pinang juga merupakan sumber ekonomi untuk sebagian orang Papua. Mama Desi adalah seorang mama asli Papua yang menjadikan pinang sebagai 
sumber pendapatannya. Lokasi penjualan pinang Mama Desi berada di jalan Basuki Rahmat Remu Utara Kota Sorong.

Untuk menjaga kelangsungan dan berkembangnya usaha penjualan buah pinang diperlukan langkah-langkah untuk dapat mengalokasi bahan baku serta meningkatkan keuntungan (laba). Karena itu diperlukan kombinasi/simulasi data penjualan pinang oleh tim pemberdayaan. Mengatasi permasalahan tersebut, dapat menggunakan metode simpleks yang merupakan bagian dari program linier.

Program Linier (PL) adalah metode optimasi untuk menemukan nilai optimum dari fungsi tujuan linier pada kondisi pembatasan-pembatasan (constraints) tertentu. Pembatasanpembatasan tersebut biasannya keterbatasan yang berkaitan dengan sumber daya seperti (Ruminta, 2014; Sarmin, L., et al., 2018) : 1) bahan mentah, 2) uang , 3) waktu, 4) tenaga kerja, dll.

Persoalan PL dapat ditemukan pada berbagai bidang dan dapat digunakan untuk membantu membuat keputusan dalam memilih suatu alternatif yang paling tepat dan pemecahan yang paling baik (the best solution). Aplikasi pemrograman linier misalnya untuk keperluan (Budiasih, Y. 2013; Dantzig, G.B. 2002) : 1) relokasi sumber daya, 2) produksi campuran, 3) keputusan investasi, 4) perencanaan produksi, 5) masalah trasportasi, logistik, dll.

Terdapat tiga elemen penting dalam PL (Mulyono, S. 2004; Basriati, S., et al., 2012; Mela, R.A., et al.,2013), yaitu: 1) Variabel keputusan (decision variables): $\mathrm{x}_{1}, \mathrm{x}_{2}, \ldots, \mathrm{x}_{\mathrm{n}}$ adalah variabel yang nilai-nilainya dipilih untuk dibuat keputusan. 2) Fungsi tujuan (objective function): $\mathrm{Z}=\mathrm{f}\left(\mathrm{x}_{1}, \mathrm{x}_{2}, \ldots, \mathrm{x}_{\mathrm{n}}\right)$ adalah fungsi yang akan dioptimasi (dimaksimumkan atau diminimumkan). 3) Pembatasan (constraints): $\mathrm{g}_{\mathrm{i}}\left(\mathrm{x}_{1}, \mathrm{x}_{2}, \ldots, \mathrm{x}_{\mathrm{n}}\right) \leq \mathrm{b}_{\mathrm{i}}$ adalah pembatasanpembatasan yang harus dipenuhi.

Tujuan dari penggunaan PL khususnya metode simpleks adalah untuk membantu Mama Desi dalam pengambilan keputusan, mempermudah menentukan dan menghitung keuntungan maksimum hasil penjualan buah pinang dalam jangka waktu 1 (satu) bulan secara akurat.

\section{MASALAH}

Berdasakan uraian pendahuluan, dirumuskan beberapa masalah yang dialami oleh Mama Desi yaitu: 1) menentukan package penjualan buah pinang, 2) menentukan strategi 
penjualan buah pinang, dan 3) proses perhitungan penjualan buah pinang yang cepat dan akurat untuk meningkatkan keuntungan dalam 1 (satu) bulan.

\section{METODE}

Metode yang digunakan dalam kegiatan ini yaitu metode simpleks, dimana digunakan dalam perhitungan untuk menghasilkan sebuah pengambilan keputusan yang baik, juga menerapkan pendekatan pendidikan masyarakat seperti melakukan pelatihan untuk menghitung bersama keuntungan dari hasil penjualan buah pinang, serta sosialisasi yang bertujuan meningkatkan pemahaman serta kesadaran, dan sebagainya. Teknik pengambilan data yang digunakan dalam kegiatan ini adalah melalui wawancara dengan penjual pinang serta observasi atau mengamati penjulan pinang yang dilakukan oleh Mama Desi.

\section{HASIL DAN PEMBAHASAN}

\subsection{Penerapan Metode Simpleks}

Berdasarkan data dari penjual Mama Desi dapat dilakukan pengelompokan atau identifikasi terhadap variabel keputusan yaitu (1lihat Gambar 1):

1) Pinang besar sebanyak 8 buah +5 buah sirih yang dijual setiap hari dengan harga Rp.20.000,-

2) Pinang kecil sebanyak 10 buah +4 buah sirih yang dijual setiap hari dengan harga Rp.10.000,-
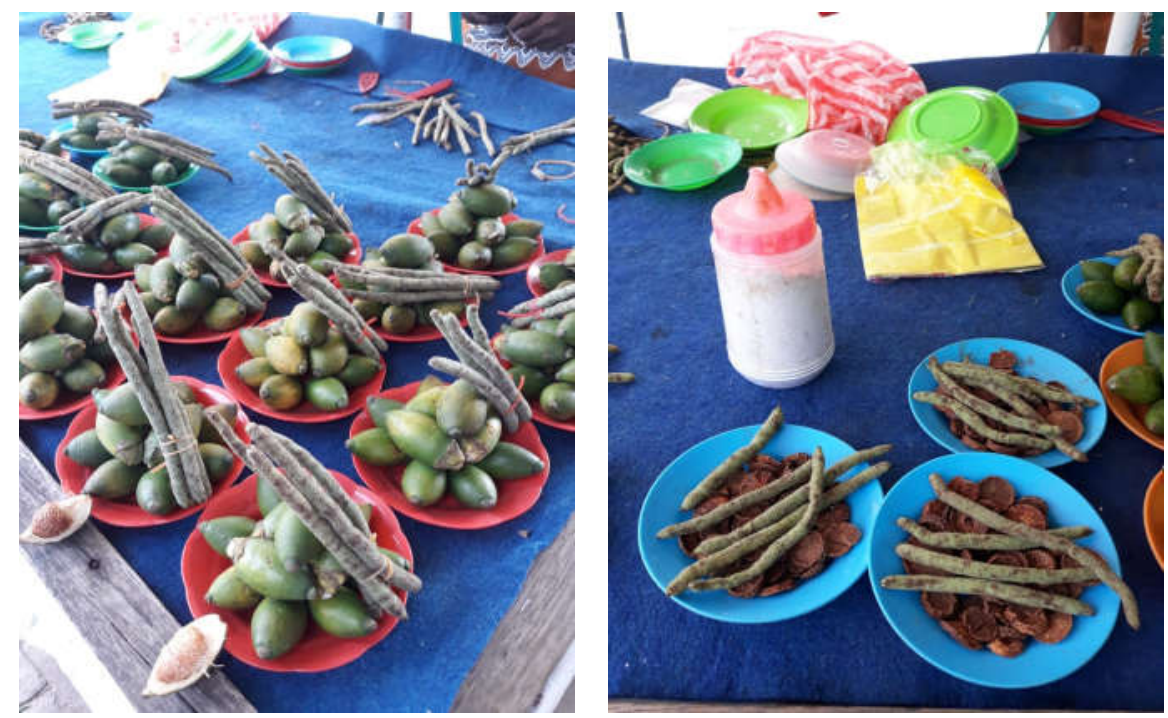

Gambar 1. Jenis Produk Pinang Yang dijual Oleh Mama Desi 
Keuntungan yang diperoleh Mama Desi dari penjualan di atas adalah untuk buah pinang besar + buah sirih sebesar Rp.200.000,- per hari (10 tumpukan) dan untuk buah pinang kecil + buah sirih keuntungan sebesar Rp.100.000,- per hari (10 tumpukan).

Untuk menentukan formulasi di atas, digunakan simbol X1, X2 dan Z dimana: $\mathrm{X} 1=$ jumlah buah pinang besar + sirih yang akan di jual setiap hari. $\mathrm{X} 2=$ jumlah buah pinang kecil + sirih yang akan di jual setiap hari. $Z=$ jumlah keuntungan buah pinang besar + sirih, buah pinang kecil + sirih, dan pinang ojek + sirih yang akan di jual setiap harinya.

Tujuan Mama Desi adalah memperoleh keuntungan sebesar-besarnya dari kendala keterbatasan sumber daya yang dimiliki maka formulasi model matematisnya adalah:

Memaksimumkan $Z=200000 X 1+100000 X 2$

Keterbatasan sumber daya dapat dibuat formulasi batasan-batasan sebagai berikut (dapat juga di lihat pada Tabel 1):

1) Pinang besar sebanyak 8 buah (X1) dan pinang kecil sebanyak 10 buah (X2) dengan kapasitas penjualan 60 tumpuk.

2) Sirih sebanyak 5 buah (X1) dan sirih sebanyak 4 buah (X2) dengan kapasitas penjualan 60 tumpuk.

Tabel 1. Jenis produk, laba dan stok

\begin{tabular}{|l|c|c|c|}
\hline \multirow{2}{*}{ Bahan baku } & \multicolumn{2}{|c|}{ Jenis produk } & $\begin{array}{c}\text { Kapasitas } \\
\text { (penjualan) }\end{array}$ \\
\cline { 2 - 3 } & Buah pinang besar & Buah pinang kecil & 60 \\
\hline Buah pinang & 8 & 10 & 60 \\
\hline Buah sirih & 5 & 4 & \\
\hline Keuntungan & Rp.200.000,- & Rp.100.000,- & \\
\hline
\end{tabular}

Data Tabel 1 dapat dibuat penyelesaian PL persoalan maksimum, langkahlangkah penyelesaiannya adalah sebagi berikut: 
Fungsi tujuan :

$Z=200000 X 1+100000 X 2$

Kendala :

1) $8 \times 1+10 \times 2 \leq 60$

2) $5 \times 1+4 \times 2 \leq 60$

1) Mengubah fungsi tujuan dan fungsi kendala

Fungsi tujuan :

$$
Z=200000 X 1+100000 X 2 \quad \Rightarrow Z Z-200000 X 1-100000 X 2=0
$$

Fungsi batasan diubah dengan memberikan variable slack yang berguna untuk mengetahui batasan-batasan dalam kapasitadengan menambah variabel tambahan menjadi:

$$
\begin{array}{lll}
8 X 1+10 \times 2 \leq 60 & =>8 X 1+10 \times 2+X 3=60 \\
5 X 1+4 X 2 \leq 60 & \Rightarrow 5 \times 1+4 X 2+X 4=60
\end{array}
$$

(X3 dan X4 adalah variabel slack)

Persamaan-persamaan diatas disusun dalam tabel simplex. Setelah formulasi diubah kemudian disusun ke dalam tabel literasi pertama sebagai berikut (lihat Tabel 2) :

2) Menyusun persamaann-persamaan ke dalam tabel!

Tabel 2. Jenis Produk, Laba dan Stok

\begin{tabular}{|c|c|c|c|c|c|c|c|}
\hline Var.dsr & $\mathrm{Z}$ & $\mathrm{X} 1$ & $\mathrm{X} 2$ & $\mathrm{X} 3$ & $\mathrm{X} 4$ & $\mathrm{NK}$ & Index \\
\hline $\mathrm{Z}$ & 1 & -200 & -100 & 0 & 0 & 0 & \\
\hline $\mathrm{X} 3$ & 0 & 8 & 10 & 1 & 0 & 60 & \\
\hline $\mathrm{X} 4$ & 0 & 5 & 4 & 0 & 1 & 60 & \\
\hline
\end{tabular}

3) Memilih kolom kunci

Kolom kunci adalah kolom yang mempunyai nilai pada baris $\mathrm{Z}$ yang bernilai negatif dengan angka terbesar. 
Tabel 3. Kolom Kunci

\begin{tabular}{|c|c|c|c|c|c|c|c|}
\hline Var.dsr & $\mathrm{Z}$ & $\mathrm{X} 1$ & $\mathrm{X} 2$ & $\mathrm{X} 3$ & $\mathrm{X} 4$ & $\mathrm{NK}$ & Index \\
\hline $\mathrm{Z}$ & 1 & -200 & -100 & 0 & 0 & 0 & \\
\hline $\mathrm{X} 3$ & 0 & 8 & 10 & 1 & 0 & 60 & \\
\hline $\mathrm{X} 4$ & 0 & 57 & 4 & 0 & 1 & 60 & \\
\hline & \multicolumn{7}{|c|}{ Kolom kunci } \\
\hline
\end{tabular}

Karena nilai X1 merupakan angka negatif paling tinggi yaitu -200 maka kolom X1 merupakan kolom pivot dan X1 merupakan variabel masuk

4) Memilih baris kunci

Memilih baris kunci, yaitu: nilai yang mempunyai limit rasio dengan angka terkecil (lihat Tabel 4).

Limit rasio $=$ nilai kanan $/$ nilai kolom kunci

$\mathrm{NK}=$ nilai kanan

Tabel 4. Baris Kunci Baris kunci

\begin{tabular}{|c|c|c|c|c|c|c|c|}
\hline Var.dsr & Z & $\mathrm{X} 1$ & $\mathrm{X} 2$ & X3 & $\mathrm{X} 4$ & NK & Index \\
\hline Z & 1 & -200 & -100 & 0 & 0 & 0 & \\
\hline X3 & 0 & 8 & 10 & 1 & 0 & 60 & 7,5 \\
\hline $\mathrm{X} 4$ & 0 & 5 & 4 & 0 & 1 & 60 & 12 \\
\hline
\end{tabular}

$\mathrm{X} 1=$ kolom kunci

$\mathrm{X} 3=$ baris kunci

Limit rasio merupakan hasil dari pembagian antara nilai kanan dengan nilai kolom kunci. Rasio pembagian nilai kanan paling kecil adalah 7,5 maka baris X3 merupakan baris pivot merupakan variabel keluar, elemen pivot adalah 8.

5) Mengubah niali-nilai baris kunci

Nilai pertama adalah nilai baris pivot baru yaitu X1, semua nilai pada baris X3 dibagi dengan 8 (elemen pivot). 
Keterangan:

a. Nilai baris kunci / angka kunci

b. Nilai kunci yaitu: nilai pada baris X3

Kolom baris kunci.

\begin{tabular}{|l|l|l|l|l|l|l|}
\hline 0 & 8 & 10 & 1 & 0 & 60 & 7,5 \\
\hline
\end{tabular}

Angka kunci, yaitu: variabel keluar/elemen pivot (8)

\begin{tabular}{|l|l|l|l|l|l|l|}
\hline 0 & $\mathbf{8}$ & 10 & 1 & 0 & 60 & 7,5 \\
\hline
\end{tabular}

Nilai baris kunci diubah dengan cara dibagidengan angka kunci, yaitu:
a. $\frac{0}{8}=0$
d. $\frac{1}{8}=0,125$
b. $\frac{8}{8}=1$
e. $\frac{0}{8}=0$
c. $\frac{10}{8}=1,25$
f. $\frac{60}{8}=7,5$

Iterasi 1, hasil pembagian dimasukkan pada baris baru yaitu X1 dimana baris X3 diubah menjadi baris X1 (lihat Tabel 5).

Tabel 5. Perubahan Baris Kunci

\begin{tabular}{|l|l|l|l|l|l|l|l|}
\hline Var.dsr & $\mathrm{Z}$ & $\mathrm{X} 1$ & $\mathrm{X} 2$ & $\mathrm{X} 3$ & $\mathrm{X} 4$ & $\mathrm{NK}$ & Index \\
\hline $\mathrm{Z}$ & 1 & -200 & -100 & 0 & 0 & 0 & \\
\hline $\mathrm{X} 1$ & $\mathbf{0}$ & $\mathbf{1}$ & $\mathbf{1 , 2 5}$ & $\mathbf{0 , 1 2 5}$ & $\mathbf{0}$ & $\mathbf{7 , 5}$ & 7,5 \\
\hline $\mathrm{X} 4$ & 0 & 5 & 4 & 0 & 1 & 60 & 12 \\
\hline
\end{tabular}

6) Mengubah nilai-nilai selain pada baris kunci

Baris baru $=$ baris lama - (koefisien per kolom kunci * nilai baris kunci).

Keterangan:

a. $\quad$ Baris lama $=$ baris $\mathrm{Z}$ dan baris $\mathrm{S} 2$

b. Koefisien per kolom kunci= nilai dari angka kolom kunci yaitu: -200 dan 8

c. Nilai baris kunci= nilai pada baris kunci baru (X1)

Perhitungan nilai baris: 


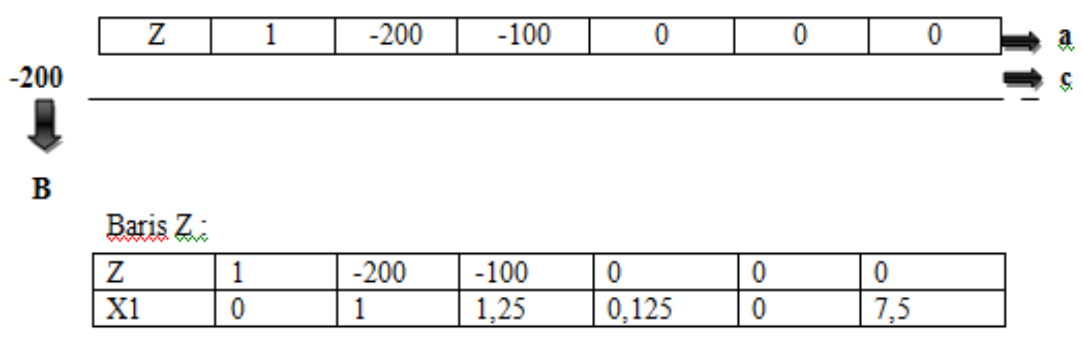

Baris baru $=$ baris lama - (koefisien per kolom kunci $*$ nilai baris kunci).
a. $\quad 1-(-200 * 0)=1$
b. $-200-(-200 * 1)=0$
c. $-100-(-200 * 1,25)=150$
d. $0-(-200 * 0,125)=25$
e. $0-(-200 * 0)=0$
f. $0-(-200 * 7,5)=1.500$

Hasil perhitungan nilai baris baru (Z)

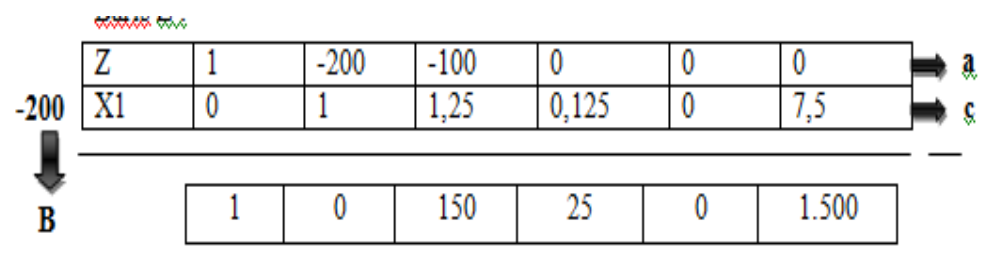

Maka hasil yang didapat dari perhitungan Baris $Z$ adalah 1,0,150,25.0,1.500.

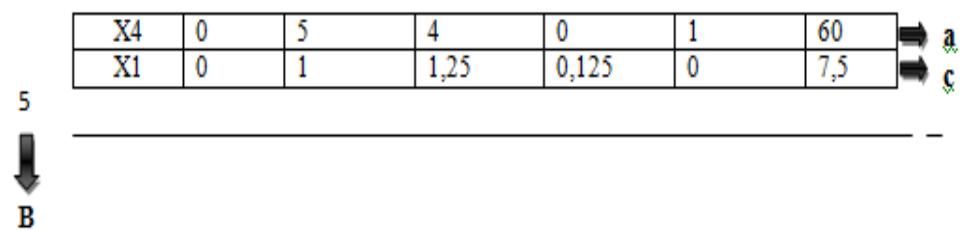

Baris baru $=$ baris lama $-($ koefisien per kolom kunci $*$ nilai baris kunci $)$.
a. $\quad 0-(5 * 0)=0$
b. $5-(5 * 1)=0$
c. $4-(5 * 1,25)=-2,25$
d. $0-(5 * 0,125)=-0,625$
e. $1-(5 * 0)=1$
f. $\quad 60-(5 * 7,5)=22,5$ 
Hasil perhitungan nilai baris baru $(\mathrm{Z})$

\begin{tabular}{|l|l|l|l|l|l|l|}
\hline $\mathrm{Z}$ & 1 & -200 & -100 & 0 & 0 & 0 \\
\hline $\mathrm{X} 1 \mathrm{7}$ & 0 & 1 & 1,25 & 0,125 & 0 & 7,5 \\
\hline
\end{tabular}

Maka hasil yang didapat dari perhitungan Baris $Z$ adalah 1,0,150,25.0,1.500.

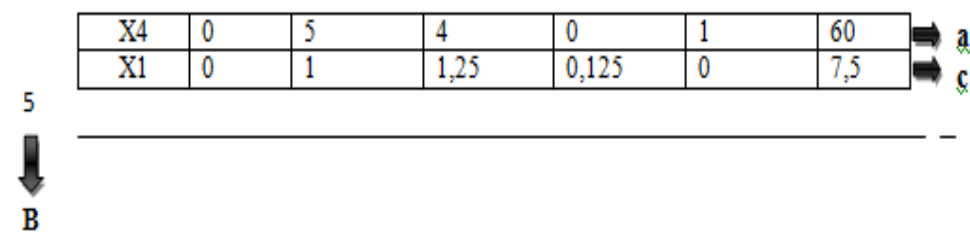

Baris baru $=$ baris lama - (koefisien per kolom kunci $*$ nilai baris kunci).
a. $0-(5 * 0)=0$
b. $5-(5 * 1)=0$
c. $4-(5 * 1,25)=-2,25$
d. $0-(5 * 0,125)=-0,625$
e. $1-(5 * 0)=1$
f. $\quad 60-(5 * 7,5)=22,5$

Hasil perhitungan nilai baris baru (X4)

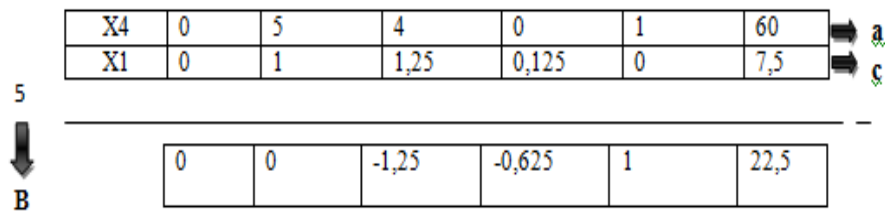

Maka hasil yang didapat dari perhitungan baris S2 adalah $\mathbf{0 ,} \mathbf{0}, \mathbf{- 1 , 2 5}$, $0,625,1,22,5$.

Maka tabel iterasi ditunjukkan pada tabel dibawah. Perhitungan tabel iterasi ke 3 sudah optimal maka perhitungan dihentikan setelah nilai pada fungsi tujuan $(Z)$ semua bernilai positif

Tabel 6. Perubahan Baris Kunci

\begin{tabular}{|l|l|l|l|l|l|l|l|}
\hline Var.dsr & $\mathrm{Z}$ & $\mathrm{X} 1$ & $\mathrm{X} 2$ & $\mathrm{X} 3$ & $\mathrm{X} 4$ & $\mathrm{NK}$ & Index \\
\hline $\mathrm{Z}$ & 1 & 150 & 25 & 0 & 0 & $1.500,000$ & \\
\hline $\mathrm{X} 1$ & $\mathbf{0}$ & $\mathbf{1}$ & $\mathbf{1 , 2 5}$ & $\mathbf{0 , 1 2 5}$ & $\mathbf{0}$ & $\mathbf{7 , 5}$ & \\
\hline $\mathrm{X} 4$ & 0 & 0 & $-2,25$ & $-0,625$ & 1 & 22,5 & 12 \\
\hline
\end{tabular}


Berdasarkan Tabel 6 di atas, baris $\mathrm{Z}$ tidak lagi ada yang bernilai negatif sehingga solusi yang diperoleh optimal, maka keuntungan maksimum yang diperoleh penjual buah pinang Mama Desi dari perhitungan dengan metode simpleks adalah Rp. 1.500.000,- per produksi penjualan buah pinang dalam 1 (satu) bulan.

\subsection{Sosialisasi Hasil Penerapan Metode Simpleks Kepada Mama Desi}

Implementasi dari penerapan metode simpleks untuk menghitung keuntungan maksimum yang diperoleh dari penjualan buah pinang dilakukan dengan cara sosialisasi. Sosialisasi ini diharapkan dapat membantu penjual pinang khususnya Mama Desi dalam menentukan jumlah package penjualan buah pinang yang awalnya hanya menjual 1 package dapat meningkat ke 2 package atau lebih, serta menentukan strategi penjualan buah pinang, sehingga Mama Desi dapat meraih keuntungan yang maksimal dalam pendapatan per bulan. Kegiatan sosialisasi ini dapat dilihat pada Gambar 2.
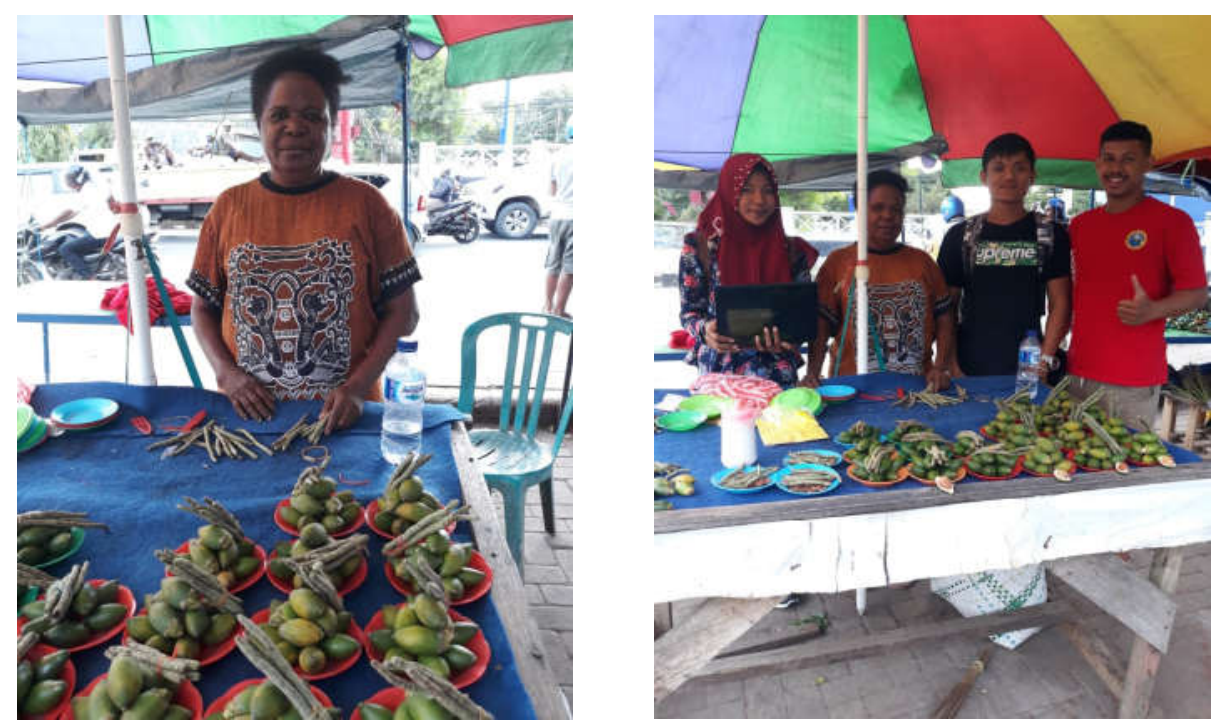

Gambar 2. Kegiatan Sosialisasi Kepada Pelaku Usaha Penjual Pinang

Kegiatan sosialisasi ini dilakukan pada tanggal 26 Januari 2019, pada pukul 15.00 - 17.00 WIT. Kegiatan ini diikuti oleh pelaku usaha penjual pinang khususnya Mama Desi. 


\section{KESIMPULAN}

Pinang merupakan buah yang sangat digemari dalam kehidupan orang Papua. Buah dari pohon pinang yang tergolong "Rumpun Palma" ini pun menjadi salah satu bagian dari tradisi masyarakat Papua. Buah pinang sangat laris diperdagangkan seperti layaknya orang menjual rokok. Tak hanya itu, buah pinang juga merupakan sumber ekonomi untuk sebagian orang Papua, seperti halnya Mama Desi. Untuk menjaga kelangsungan dan berkembangnya usaha penjualan buah pinang diperlukan langkah-langkah untuk dapat mengalokasi bahan baku serta meningkatkan keuntungan (laba). Oleh sebab itu, diperlukan teknik atau suatu metode dalam menentukan kombinasi yang tepat dari penjualan. Mengatasi permasalahan tersebut, dapat menggunakan metode simpleks yang merupakan bagian dari program linier. Penerapan metode simpleks menjadi salah satu solusi untuk menyelesaikan permasalahan optimasi penjualan buah pinang, sehingga dapat membantu memaksimalkan keuntungan dari keterbatasan sumber daya yang dimiliki oleh Mama Desi. Kegiatan pengabdian masyarakat yang dilakukan ini dapat meningkatkan pemahaman para pelaku usaha penjualan pinang seperti halnya Mama Desi dalam menghasilkan keuntungan maksimum dari keterbatasan sumber daya yang dimiliki.

\section{DAFTAR PUSTAKA}

Basriati, S., Lestari, P.A. (2012). Optimasi Pemasaran Produk Susu Pada PT. Indomarco Adi Prima Pekanbaru Menggunakan Metode Simpleks. Jurnal Sains, Teknologi dan Industri. Vol. 9, No.2.

Budiasih, Y. (2013). Maksimalisasi Keuntungan Dengan Pendekatan Metode Simpleks Kasus Pada Pabrik Sosis SM. Jurnal Liquidity. Vol.2, no.1, pp.59-65.

Dantzig, G.B. (2002). Linear Programming. Operation Research, vol. 50, no.1, pp. 42-47.

Mela, R.A., Putra, D.N., Murniati, S., Mustahiroh, Octavia, D., Budiasih, Y. (2013). Maksimalisasi Keuntungan dengan pendekatan Metode Simpleks Studi Kasus Pada Pabrik Sendal X di Ciputat, Tanggerang Selatan. Jurnal Liquidity. Vol.2, no.2, pp.144150. 
Mulyono, S. (2004). Riset Operasi. Jakarta: Penerbitan Fakultas Ekonomi Universitas Indonesia.

Ruminta. (2014). Matriks Persamaan Linier dan Pemrograman Linier Edisi Revisi. Bandung: Rekayasa Sains.

Sarmin, L., Ridelviani, Karubuy, K., Rumetna, M.S., Lina, T.N. (2018).Penerapan Metode Simpleks Untuk Menghitung Keuntungan Maksimum Pada Pengrajin Gelang Besi Putih di Pasar Remu Sorong. Jurnal KUADAS. Vol.1, no.2. pp.99-106. 